\title{
IN HOEVER IS UITBREIDING VAN DE WET OP DEN KINDERARBEID WENSCHELIJK EN UITVOERBAAR?
}

't Is een meermalen waargenomen karaktertrek van ons volk, dat het zich hoogst moeilijk een overtniging omtrent een zaak van algemeen belang laat vestigen; maar heeft dat eens plaats gevonden, dan wordt met grooten ijver en eenstemmigheid aan hare verwezenlijking gearbeid.

Dit verschijnsel heeft zich weder geopenbaard bij het tot stand komen van de wet houdende maatregelen tot het tegengaan van overmatigen arbeid en verwaarloozing van kinderen.

Nadat meer dan vijf en twintg jaren de quaestie van den kinderarbeid ten onzent is besproken en de regeering gedrongen werd hare tusschenkomst tot bescherming der kinderen te verleenen, neemt eindelijk een der volksvertegenwoordigers het initiatief. $\mathrm{H}_{\mathrm{ij}}$ wordt krachtig ondersteund door "het volk" zelf, dat de overtuiging uitspreekt, dat het noodig is een einde te maken aan een toestand, die het kind lichamelijk en zedelijk-verstandelijk schaadt.

Het beginsel door het volk vitgesproken werd door de vertegenwoordiging tot wet verheven en door ${ }^{-}$den Koning gesanctioneerd: "het is verboden kinderen beneden twaalf jaren in dienst te nemen of in dienst te hebben."

Volle toepassing heeft dat beginsel vooralsnog niet gevonden, want het verbod is niet toepasselijk op huiselijke en persoonlijke diensten en op veldarbeid.

De wetgever ging van de overweging uit, dat eenige maatregelen behooren te worden genomen, ten einde overmatigen arbeid en verwaarloozing van kinderen tegen te gaan.

Aan het laatste vereischte is eenigermate voldaan; tegen overmatigen arbeid van kinderen behelst die wet geenerlei maat. egel.

Met prijzenswaardigen ijver schijnt de regeering in deze en andere leemten van de wet te willen voorzien, nadat de termijn nauwelijks is verstreken, waarop de wet volle toepassing zou krijgen. 
De vraagpunten, begeleidende de circulaire van den Minister van Justitie aan de Kamers van Koophandel en Fabrieken en aan de Besturen der Maatschappijen van Landbonw gericht, strekken daarvan ten bewijze.

De publiceering van die vraagpunten heeft ook van andere zijden daaromtrent meeningen uitgelokt.

'Je Economist, die geacht mag worden het eerst de aandacht van het publiek op dit onderwerp in ons land gevestigd te hebben en die wellicht veel heeft toegebracht tot de verwezenlijking van wettelijke regeling, meende ook nu haar oordeel niet te moeten achterwege houden.

De geachte redacteur droeg mij de vereerende taak op, hierover een kort woord in het midden te brengen.

Ofschoon ik tegen het moeielijke van die taak wel eenigzins opzag, meende ik mij daaraan niet te mogen onttrekken, omdat ik de vrees voor overijling of het betreden van zijwegen niet ongegrond acht. Als men zoo wat twintig jaren een onderwerp bestudeerd en van alle zijden bekeken heeft, en men dan geroepen wordt over een concreet geval zijn oordeel uit te spreken, dan vraagt men niet zoozeer wat wenschelijk, maar meer wat uitvoerbaar, bereikbaar is?

't Is toch niet genoeg bij eene wet te decreteeren: dit of dat is verboden; het verbod moet blijken heilzaam en uitvoerbaar te zijn. Een wet die niet naar behooren wordt gehandhaafd, brengt de waardigheid van den wetgever in miscrediet; een wet die alleen door strenge strafbepalingen kan gehandhaafd worden, is een drukkende last, werkt verlammend in plaats van verlevendigend, doet meer kwaad dan goed.

Van dat beginsel uitgaande, wenschen we de gestelde vragen aan een onderzoek te onderwerpen.

De eerste vraag dan, of bij een mogelijke vitbreiding de wet, naast een volstrekt verbod van arbeid van kinderen beneden een bepaalden leeftijd, ook voorschriften moet inhouden tegen overmatigen arbeid van kinderen boven den leeftijd en van jongelieden, dient in bevestigenden zin te worden beantwoord. Zal de overweging, waardoor deze wet is in het leven geroepen, recht van bestaan erlangen, dan is aanvulling in laatstgenoemden zin noodig. Door verbod van loongevenden arbeid beneden den leeftijd van 12 jaren wordt een waarborg geschonken tegen zedelijk-verstandelijke verwaarloozing der kinderen. Stelt men echter het meisje of de knaap na dien leeftijd bloot aan overmatigen arbeid, dan wordt 
een gereede aanleiding tot physiek verval gegeven. Overmatige arbeid in de eigenlijke ontwikkelingsjaren tot de manbaarheid, waartoe de levensperiode van 12-16 jaren gerekend moet worden, kan evenveel schaden als in den kinderleeftijd. De beenvorming is over het geheele skelet nog niet voltooid, de banden en spieren zijn nog te zwak, om langen tijd achtereen inspannenden lichaamsarbeid te verrichten. De organen van twee gewichtige functiën, der ademhaling en der geslachtsverrichting, verkeeren op dit tijdstip in een toestand van ontwikkeling, die met de meeste omzichtigheid bewaakt moet worden.

De knaap en het meisje worden door den arbeid in fabrieken en werkplaatsen vaak in omstandigheden geplaatst, die noodlottige gevolgen voor hun physiek bestaan kan opleveren. Die omstandigheden zijn van verschillenden aard: slechte gesteldheid van de lokaliteit, schadelijkheid van de werktuigen en van de grondstoffen, langdurige en ongeschikte werktijd, arbeid die de krachten te bovengaat.

Een regeering, die tegen physiek verval door den arbeid van niet volwassen personen wil waken, dient met al die omstandigheden rekening te houden en niet enkel hare aandacht te schenken aan het begrip overmatigen arbeid. Bovendien is het begrip novermatige arbeid" iets zeer subjectiefs on in gewone gevallen moeielijk uit te maken, zeker moeielijk te generaliseeren. Een grens te trekken, waar een arbeid overmatig genoemd moet worden, is in de praktijk lang niet gemakkelijk. Men dient daarbij te individualiseeren en bovendien rekening te houden met de bovengenoemde en ook met andere omstandigheden buiten het werk, vooral de voeding, aanwezig.

Het is dus altijd een greep in den blinde, te bepalen, dat het werken gedurende een zeker antal uren daags voor kinderen van een bepaalden leeftijd, tegen overmatigen arbeid vrijwaart.

Dit bezwaar is echter onvermijdelijk, wanneer de eerste stap tot wettelijke regeling van dit onderwerp is gedaan. Wij hebben vroeger aangetoond, wat de Engelsche regeering in dit opzicht zich genoodzaakt zag te doen en wat, in navolging ran haar, andere landen hebben gedaan.

De Nederlandsche regeering kan er dus niet buiten; om, getrouw aan de overwegingen van de bestaande wet, bij eventueele uitbreiding, den arbeidsduur van jongelieden te regelen.

Zij moet die grens echter aanvankelijk zóo ver mogelijk stellen, om van stap tat stap die te beperken. Op gevaar af, dat nog bij 
vele soorten van arbeid overmatig zal worden gewerkt door jongelieden, beperke zij aanvankelijk den arbeidsduur zoo weinig mogelijk. Daarom zouden wij voor het verrichten van loongevenden arbeid beneden 16jarigen leeftijd slechts nachtwerk willen hebben verboden, of, wil men een tijd aangeven, te bepalen dat vóór 6 uur des voormiddags en na 8 uur des namiddags zoodanige arbeid door jongelieden niet mag worden verricht. De ervaring zal nu moeten leeren in hoever die grens te ver is gesteld en welke meer in overeenstemming met de eischen van den jeugdigen werkman on van de industrie is.

In de tweede plaats moet het volstrekt verbod van kinderarbeid beneden 12 jaren niet alleen gehandhaafd, maar noodzakelijk uitgebreid en toepasselijk gemaakt worden ook op veldarbeid. De onderzoekingen op dit gebied na het in werking treden der bestaande wet ingesteld, hebben duidelijk genoeg aangetoond, dat een verbod van veldarbeid beneden dien leeftijd even nuttig en uitvoerbaar is, als in fabrieken en werkplaatsen.

Ons dunkt dat in een wet, die zich alleen ten doel stelt de beperking van den arbeid van kinderen en jongelieden, van een regeling van den arbeid van volwassen vrouwen geen sprake kan zijn. Men zou daarbij een gebied betreden, dat geheel vreemd aan staatsbemoeiing moet blijven. Staatsvoogdij is alleen geoorloofd tegenover onmondigen. De volwassen vrouw moet vrij in en toerekenbaar voor hare handelingen blijven. Aan haar dus de keuze over den duur en de soort van arbeid, waartoe zij zich wil leenen.

Ten aanzien van eene verklaring door een geneeskundige afgelegd, dat de krachten van den persoon toereikend zijn voor den arbeid, dien hij te verrichten heeft, moeten wij opmerken, dat zulk een verklaring in gemoede noode is geven, en dat in deze het scherpziend oog van den patroon beter kan oordeelen dan een geneesheer. In Engeland wordt dit hulpmiddel te baat genomen bij gemis van nauwkeurige geboorteacten. Die keuring geeft daar echter tot vele bezwaren aanleiding en stelt de deur voor veel misleiding open: Luide klachten worden daarover dan ook vernomen. Daarbij komt, dat zulk een geneeskundig keurmeester beter in het kader van de Engelsche wetgeving past dan van de onze. De districtofficer of health neemt daar tevens de functiën van fabriekarts waar. Hij wordt dan ook geacht met de eischen van den arbeid vertrouwd te zijn. Afzonderlijke geneesheeren ten onzent daarvoor aantestellen, zou een uitgebreid en kostbaar personeel vorderen. 
Na het reeds medegedeelde omtrent de regeling van den arbeidsduur zullen wij niet noodig hebben het half-time systeem an to bevelen, dat trouwens zonder wettelijke invoering van schooldwang - de eenige contrôle - geen reden van bestaan zou hebben.

Ook voor het verleenen van vrije dagen op wettelijk voorschrift bestaat niet de minste grond. Onze werklieden weten den vrijen tijj nog niet aangenaam en nuttig te besteden, om hun nog meer dan den eersten dag der week en de gewone kerkelijke en maatschappelijke vrije dagen gelegenheid te geven tot ontspanning. Bij de tegenwoordige zucht naar vermaak ook bij den arbeidenden stand en de veelal buitensporige uitgaven om daaraan te voldoen, geve de wet daartoe niet meer aanleiding.

De breede grondslag, waarop de bestaande wet is gevestigd, dient de regeering niet in te krimpen, maar zoo mogelijk uit te breiden. Vandaar, dat wij bij eventueele uitbreiding de bepalingen toepasselijk wenschen gemaakt te zien op allen voor loon verrichten arbeid door kinderen beneden de 16 jaren. Daarbij vervalt dan ook de moeielijke definitie van fabriek en werkplaats.

Met het oog op het moeilijk controleerbare zouden wij vooralsnog de bepaling van de bestaande wet, die ${ }$ huisselijke en persoonlijke diensten" uitsluit, voor kinderen boven de 12 jaren gehandhaafd wenschen te zien.

Ten aanzien van de laatste, onzes inziens, alles beheerschende vraag omtrent het vereischte van afzonderlijke inspecteurs, om to waken voor de nakoming der nieuwe wet, kan het antwoord niet dan bevestigend luiden. Zonder zulk een speciaal toezicht zal noch de bestaande, noch een uitgebreide wet voldoende aan haar doel beantwoorden. Het was een leemte in het oorspronkelijke voorstel van den heer van Houten, dat voor het toezicht geene afzonderlijke ambtenaren waren aangewezen, een leemte, waarop bij het debat over het voorstel bij herhaling is gewezen, eene leemte die niet is aangevuld nu de regeering de tot wet verheven bepalingen onder toezicht der politie heeft gesteld. Wat daarvan is terecht gekomen is meer geluk dan wijsheid. Onder den eersten indruk van de invoering der wet zijn een aantal minderjarigen uit de fabrieken en werkplaatsen verwijderd, maar het allerminst op aandrang van de politie. Het politietoezicht heeft veel oogluikend toegelaten. Omtrent de werking van de wet is dan ook niets met zekerheid bekend, althans niet tot algemeene bekendheid gekomen. Naar het gering aantal bekeuringen te oordeelen, die in groote steden hebben plaats gehad, en bij de klachten over bestaande misbruiken, mag 
men tot eene geringe activiteit van de gestelde macht besluiten. En dat was niet anders te verwachten bij het gemis van andere voorschriften, dan de wet behelst. Van den omslachtigen weg, om zich van den juisten leeftijd der kinderen te overtuigen alleen bij den ambtenaar van den burgerlijken stand, wordt in den regel, noch door de werkgevers, noch door de politie gebruik gemaakt. Van daar zooveel wetsovertreding, wetsontduiking, verzuim om de wet streng te handhaven.

Strikte handhaving van de wet kan alleen van een nauwkeurig, stelselmatig onderzoek door speciale, verantwoordelijke ambtenaren verwacht worden. Deze en de werkgevers moeten weten welke voorschriften in acht moeten worden genomen, om de wet goed te kunnen handhaven.

Het toezicht van de politie behoort echter behouden te blijven, wil men niet in een stelsel van plaatselijke inspecteurs vervallen, dat zeer kostbaar zou worden. Maar de plaatselijke politie worde ondergeschikt gemaakt aan de provinciale of district-inspecteurs.

Een wetgeving op dit stuk is een arbeid, die jaren lang onderzoek en voorbereiding vordert. De gegevens voor eene volledige wetgeving bezitten wij allerminst, hoeveel daarovẹr ook moge geschreven zijn, hoe dikwijls er van enquêtes sprake is geweest. De ingestelde enquêtes hebben weinig omtrent de regeling van den arbeid, allerminst omtrent den overmatigen arbeid aan het licht gebracht. Ook omtrent de régime van de werkplaats weten we weinig of niets. Dit alles moet door een gestadig en nauwgezet onderzoek van onpartijdige zaakkundigen worden nagegaan. $\mathrm{Zij}$ moeten gegevens verzamelen voor eene eventueele uitbreiding van de wet.

Van stap tot stap moet die uitbreiding plaats hebben en niet dan nadat de noodzakelijkheid uit ervaring daarvoor gebleken is te bestaan. Het gaat niet aan bij zulk een onderwerp zich tot bloote navolging van andere landen te bepalen. Men moet rekening houden met de volksgewoonten en volksbehoeften. Onze arbeidsregeling is een uitvloeisel van ons maatschappelijk leven en heeft het eigenaardige van ons volkskarakter. Dat mag niet worden voorbijgezien. Ruw ingrijpen in de gebruiken en regeling van den arbeid is inbreuk maken op de vrijheid van den staatsburger en streeft het goede doel voorbij. Bedachtzaam voortschrijden is hier dus een eerst vereisehte. Overijling leidt tot verkeerde handelingen en zou het eens zoo goed aangevangen werk in miscrediet brengen. De volksovertuiging en de algemeene belangstelling moeten meer 
en meer voor deze materie gevestigd worden. Heeft de volksmeening zich verklaard voor uitbreiding of wijziging, dan dient de regeering aan die stem gehoor te geven. Dan alleen kan zij verwachten, dat hare voorschriften gewillig en nauwgezet zullen worden nageleefd.

Wij onthouden ons dus vooralsnog om andere bepalingen te bespreken, die een even heilzame strekking zouden hebben als die tegen overmatigen arbeid moeten beschermen, ofschoon ze later noodwendig een plaats in een wet tot bescherming van kinderen, die lichamelijken arbeid verrichten, moeten vinden. Wij bedoelen de voorschriften tegen schadelijke invloeden van gebouwen, grondstoffen en werktuigen.

Ook daaromtrent bezitten wij nog te weinig gegevens, om er wettelijke bepalingen tegen te maken. Die onderwerpen moeten eerst door nauwgezette studie worden nagegaan. Wij zouden ook deze taak aan de inspecteurs wenschen op te dragen. Blijkt na een genoegzame ervaring, dat het noodig is hierin te voorzien, dan zal tevens de weg kunnen worden aangewezen, op welke wijze dit het geschiktst zal kunnen geschieden.

Vatten wij ten slotte onze beschouwingen in korte woorden samen, dan wenschen wij, dat eene eventueele uitbreiding van de wet zich bepale tot:

10. uitbreiding van het verbod tot elken arbeid die voor loon wordt verrieht door kinderen beneden de 12 jaren (huiselijke en persoonlijke diensten hiervan uitgezonderd);

20. het verbod van nachtelijken arbeid (vóór 6 uur des voormiddags en na 8 uur des namiddags) van jongelieden van beider kunne beneden den leeftijd van 16 jaren;

30. aanstelling van speciale ambtenaren met het toezicht op de handhaving der wet belast.

S. Sr. Coronel. 